\title{
V16 - PADRONIZAÇÃO DE PCR EM TEMPO REAL (TAQMAN) PARA QUANTIFICAÇÃO DE VIRUS 17DDENGUE RECOMBINANTES CANDIDATOS A VACINA TETRAVALENTE EM AMOSTRAS BIOLÓGICAS
}

Gisela Freitas Trindade ${ }^{1}$, Sheila Maria Barbosa de Lima ${ }^{1}$, Vanessa Salete de Paula ${ }^{2}$, Marcia Archer da Motta ${ }^{1}$, Anna Maya Yoshida Yamamura ${ }^{1}$.

1- Bio-Manguinhos, Fundação Oswaldo Cruz, Desenvolvimento Tecnológico, Rio de Janeiro, Brasil.

2- Instituto Oswaldo Cruz, Fundação Oswaldo Cruz, Rio de Janeiro, Brasil.

Introdução: A introdução de novos produtos e serviços de qualidade para ampliar o acesso da sociedade brasileira a insumos estratégicos de saúde é o principal objetivo de Bio-Manguinhos, que para isso investe constantemente em pesquisa, desenvolvimento e inovação com foco nas demandas de saúde pública do país. Dentro da carteira de projetos da Vice-Diretoria de Desenvolvimento Tecnológico (VDTEC), se insere o projeto "Uso do vírus amarílico vacinal 17D para a expressão de antígenos de Dengue visando o desenvolvimento de novas vacinas vivas atenuadas". O projeto consiste no desenvolvimento de uma vacina tetravalente viva atenuada quimérica de Dengue-Febre Amarela, através da substituição da região prM/E, que codifica as proteínas de membrana e de envelope do vírus Dengue em um clone da linhagem vacinal 17D do vírus da Febre Amarela.

Metodologia: Para acompanhar a cinética in vitro e in vivo de propagação viral dos vírus recombinantes 17DDengue (1-4), é de grande interesse a aplicação da técnica de PCR quantitativo em Tempo Real (qPCR) que permita avaliar de forma eficaz e rápida o cultivo dos vírus em cultura celular, bem como a viremia produzida em modelos animais pós-vacinação. Neste sentido, a técnica de qPCR está em fase de padronização no Laboratório de Tecnologia Virológica (LATEV).

Resultados: Os oligonucleotídeos iniciadores foram desenhados de forma a amplificar uma sequencia de junção entre os genes do envelope (Dengue) e NS1 (Febre Amarela) 
para garantir que apenas o genoma de vírus quiméricos seja detectado. As concentrações de oligonucleotídeos iniciadores $[300 \mathrm{nM}]$ e de sondas $[150 \mathrm{nM}]$ a serem utilizadas já foram definidas. Além disso, foram testadas sondas com marcação para diferentes fluoróforos (FAM, VIC, NED) a fim de aprimorar a eficiência no estabelecimento de um teste biplex, ou seja, uma reação capaz de discriminar diferentes sorotipos de vírus quiméricos presentes na mesma amostra biológica. As clonagens no vetor TOPO para obtenção das curvas padrão para quantificação da carga viral estão em andamento, o que tornará possível a determinação do número de cópias do genoma viral e sua correlação com o título viral obtido pela técnica de plaqueamento.

Conclusões: $O$ desenvolvimento desta metodologia tem como finalidade otimizar o tempo para obtenção do título viral de amostras em cultura e a tomada de decisões em um processo de escalonamento de produção viral. Da mesma forma, este teste será aplicado na titulação dos antígenos vacinais circulantes nos animais testados em estudos préclinicos desta vacina recombinante. 